\title{
Sanctus Amor (1908) Нины Петровской как жизнетворческий манифест
}

\author{
Nina Petrovskaya's Sanctus Amor (1908) \\ as a life-creating manifesto
}

\begin{abstract}
Sanctus Amor is the only intravital storybook by Nina Petrovskaya, dedicated to Sergey Auslender. The title of the book, borrowed from the poem by Andrey Bely, initiates a literary polylogue addressed to several lovers of Petrovskaya: to Bely, as he once was her teacher of heavenly love; to Valery Bryusov, as he was Petrovskaya's beloved one at the time of publication; to Auslender as the addressee of dedication and a new contender for being Petrovskaya's favorite. Sanctus Amor represents the ideal of the Saintly Love, the manifesto which Petrovskaya followed rigorously in real life. Her letters to Bryusov and Vladislav Khodasevich reveal multiple congruences with the novels of Sanctus Amor, which demonstrate the inextricable character of life and literature in Petrovskaya's worldview. The paper is devoted to the analysis of Sanctus Amor in the aspect of life-creating practices and its meaning in the literary dialogue with Auslender. Sanctus Amor is a complicated prescriptive symbolic message designed to proclaim its own, and to program another's, concept of love.
\end{abstract}

Keywords: Nina Petrovskaya, Sergey Auslender, Sanctus Amor, life-creation, symbolism

Aleksey Samarin, University of Tartu, Tartu - Estonia, fent@inbox.lv, ORCID ID: https://orcid. org/0000-0001-6429-4616

Sanctus Amor - первый и единственный прижизненный сборник рассказов Нины Петровской - был опубликован в конце 1907 года (на титульном листе значится „1908”) в книгоиздательстве „Гриф”, принадлежавшем ее бывшему мужу Сергею Соколову. На листе, следующем за титульным, крупными заглавными буквами значится: „Посвящаю Сергею Ауслендеру”. К моменту выхода сборника у Петровской еще не закончился роман с Валерием Брюсовым, и логичнее было бы посвятить дебютную книгу ему, тем более что с Ауслендером писательница познакомилась всего за полгода до этого, когда большая часть рассказов была уже написана. Каковы бы ни были первоначальные импульсы создания рассказов, посвящение задавало новую 
рамку для их интерпретации в контексте отношений двух начинающих прозаиков, ослабляя роль брюсовского фона и побуждая читателя к поиску связей с творчеством Ауслендера.

Современная критика не оставила книжку Петровской незамеченной, хотя мнения рецензентов о ней разошлись. По́ходя и весьма пренебрежительно о ней упомянула Зинаида Гиппиус в статье Зверебог, посвященной половому вопросу (Gippius 331). Сдержанной, но благожелательной рецензией откликнулся Андрей Белый (Belyj 90). Петр Пильский опубликовал рецензию-фельетон Будуарная литература: Мимочка в литературе (Pil'skij 2), в которой, по замечанию Кирсти Эконен, заменил анализ сборника Sanctus Amor подборкой цитат из сатирической трилогии В. Микулич (Лидия Ивановна Веселитская) Мимочка - невеста, Мимочка на водах и Мимочка отравилась (Èkonen 265). Заметим, что в сентябре 1907 года Петровская опубликовала („Весы” № 9) крайне негативную рецензию на сборник Пильского Рассказы, что также могло послужить причиной для ответной критики (Mihajlova 773). Критик П. Костаньян „оказался способным оценить рассказы Петровской и уловить их своеобразие”, как отметил Александр Лавров, посвятивший несколько абзацев сборнику в статье Валерий Брюсов и Нина Петровская: Биографическая канва к переписке (Lavrov 2004: 16). Анонимный рецензент опубликовал в газете „Волга” короткую заметку, в которой отметил, что „глубокая богатством трагических переживаний” книга Петровской „написана превосходным языком” („Novosti literatury”). „Столь же благожелательным, - по словам Марии Михайловой, - был и отзыв на страницах одесской газеты «Голос» (1908. № 1. С. 4)” (Mihajlova 772). В частности, критик отметил „в авторе глубоко-серьезное отношение к неизменной” теме рассказов - любви, а также указал на влияние Кнута Гамсуна: „Бесспорное влияние Гамсуна уравновешивается у Нины Петровской остротой и сложностью личных переживаний и, следовательно, оставляет должный простор для самостоятельного творчества" (Mihajlova 772). Высоко отозвался о сборнике А. Тимофеев („Руль”, № 117, 1908, с. 5), обнаружив в нем сходство с прозой Антона Чехова:

Как бы не характеризовали мы Чехова - нам все равно придется [...] употребить эпитет „нежный”. У Нины Петровской эта нежность вытекает из женского начала ее природы, ее душевной организации, и в соединении с чертами мужскими [...] дает тот обольстительный колорит, который чувствует всякий, читая Sanctus Amor (цит. по: Mihajlova 773).

С научной точки зрения сборник освещен в статье Кирсти Эконен, которая интересуется нарративными стратегиями и идеологическими установками Петровской (Èkonen). Нас же интересует жизнетворческая прагматика сборника, его роль в литературном диалоге Нины Петровской и Сергея Ауслендера. 
Писатели познакомилась в августе 1907 года в Москве, куда Ауслендер приехал, чтобы посетить редакцию журнала „Весы”. К этому времени Петровская находилась в любовной связи с Брюсовым, который отвечал ей пылкой взаимностью, но

явно не хотел [...] осложнять свою семейную жизнь: жена его, Иоанна Матвеевна, не могла оставаться в неведении относительно того, о чем уже судачила вся литературная Москва (Lavrov 2004: 15).

Очевидно, что уже тогда между Петровской и Ауслендером возникла связь. В сентябре она посетила Ауслендера в Петербурге, а весной следующего года они отправились в путешествие по Италии. Sanctus Amor вышел в свет накануне поездки, получив значение своеобразной экспозиции этого жизнетворческого „сюжета”.

Ряд рассказов описывает ситуацию любовного треугольника и невозможности счастливого союза героев. Эта модель, основанная на реальных отношениях Брюсова, Петровской и третьего лица, в результате посвящения новому знакомому требовала переосмысления и перераспределения ролей. Реинтерпретация модели началась уже в письмах Петровской из Петербурга. Так, в одном из писем к Брюсову она пишет, что Ауслендер уже в первую встречу „говорил, что очень ее любит” (Brûsov, Petrovskaâ 237). Образ Ауслендера как безнадежно влюбленного мальчика она продолжит конструировать и в письмах из Италии. Однако Владислав Ходасевич, друг и конфидент Петровской, сохранил в мемуарах и другую по окраске трактовку событий: „Вдруг приехала Нина Петровская, гонимая из Москвы неладами с Брюсовым и минутной угарной любовью к одному молодому петербургскому беллетристу" (Hodasevič 52).

По мнению Рема Щербакова и Елизаветы Муравьевой, со слов Ходасевича излагает эту историю в своих воспоминаниях и Борис Садовской: „Нина Петровская с первого взгляда влюбилась в Ауслендера и решила увезти его в Италию" (Ŝerbakov, Murav'eva 384).

Такая трактовка отразилась пять лет спустя и в собственном романе Ауслендера Последний спутник (1913). Противоречие взаимно конструируемых образов (в литературе - Ауслендером, в письмах - Петровской) представляется достойным отдельного разбора. Адресатом писем Петровской был Брюсов, в глазах которого писательница с большой вероятностью желала создать образ именно безнадежно влюбленного и заведомо отвергнутого Ауслендера; напротив, адресатом текстов Ауслендера была широкая аудитория, а Петровская представляла наиболее осведомленную ее часть, способную „прочитать” интимный пласт сообщения. В статье Текст и структура аудитории Юрий Лотман писал о том, как текст меняет своего читателя: 
Явление это связано с тем, что всякий текст (в особенности художественный) содержит в себе то, что мы предпочли бы называть образом аудитории, и что этот образ аудитории активно воздействует на реальную аудиторию [...] навязывается сознанию аудитории и становится нормой ее собственного представления о себе, переносясь из области текста в сферу реального поведения культурного коллектива. Таким образом, между текстом и аудиторией складывается отношение, которое характеризуется не пассивным восприятием, а имеет природу диалога (Lotman 169).

В разбираемом случае этот вид коммуникации получает формальное выражение и в диалоге двух книг - Sanctus Amor Петровской и Последний спутник Ауслендера (см. Gračeva; Samarin). При этом следует учитывать, что сборник Петровской оказывается скорее программирующим текстом предлагаемой Ауслендеру поведенческой и мировоззренческой моделью, которую он мог либо принять, либо отвергнуть. Последний спутник, напротив, выступает в роли ретроспективной дескриптивной модели, что, конечно, не лишает его воздействия на аудиторию. Настоящая статья посвящена анализу первой „реплики” в описанном диалоге и экспликации художественно зашифрованного „послания” Петровской адресату посвящения.

Общая структура. Сборник Sanctus Amor состоит из десяти небольших рассказов. Большинство из них к моменту выхода сборника уже публиковались в периодических изданиях: восемь - в том же 1907 году, один (Раб) в 1906 году, и в одном случае (Призраки) не удалось установить, была ли отдельная публикация. Приведем список рассказов с указанием выходных данных первой публикации:

1) Она придет （,Перевал”, № 8-9, 1907)

2) Ложь (Корабли. Сборник стихов и прозы. Москва, 1907)

3) Раб (,Перевал”, № 2, 1906)

4) Весной („Новь”, 2 марта 1907)

5) Я и собака („Столичное утро”, № 33, 7 июля 1907)

6) Бродяга („Голос Москвы”, 26 июля 1907)

7) Северная сказка („Накануне”, 1 июля 1907)

8) Призраки

(?)

9) Осень („Перевал”, № 12, 1907, с. 51-53.)

10) Любовь („Голос Москвы”, 30 ноября 1907)

Мысль о составлении и публикации собственного сборника, по-видимому, уже некоторое время занимала Петровскую, о чем можно судить, например, по ее письму к Ходасевичу от 29 апреля 1907 года: 
Как Вы посоветуете, - ведь книга исключительно будет посвящена любви, - я написала три „песни любви” и их хочу в первую голову? Не бойтесь, не стихами, этого не могу. Приличной [...] культурной прозой по форме вроде Песен Билитис. И лучше Галунова, клянусь! Очень любовно (Ŝerbakov, Murav'eva 373 ).

7 июля 1907 года Петровская предлагает Ходасевичу вместе выпустить свои сборники в сентябре, так как известие „о ближайшем выходе [...] книг было чуть не в 3-х газетах" (Ŝerbakov, Murav'eva 385). Очевидно, что большинство ,песен любви” (по меньшей мере, № 1, 3-7) она написала до знакомства с Ауслендером, а значит, и решение посвятить книгу ему принимала в довольно сжатые сроки (в течение осени). Учитывая высокую сюжетно-тематическую и образную близость рассказов, можно предположить, что Петровская сочла возможной не частичную, а полную ретрансляцию Ауслендеру сообщения, исходно предназначенного Брюсову. Для истолкования этого сообщения мы произвели анализ сборника на композиционном, сюжетно-тематическом, идейном и образном уровнях, а также, по мере возможности, привлекли для интерпретации рассказов историко-биографический материал.

Обращаясь к анализу Sanctus Amor, Эконен отмечает, что сборник „содержит десять вариаций на тему несчастной любви между мужчиной и женщиной” (Èkonen 271), а также предлагает объединить рассказы в четыре тематические группы следующим образом:

I. Нереалистические ожидания мужчины (Она придет, Весной, Я и собака);

II. Мужчина переживает краткую „настоящую любовь” с незнакомой женщиной (Ложь, Бродяга, Раб);

III. Любовь не повторяется - она возможна только раз (Северная сказка, Осень);

IV. Любовь ведет к смерти (Призраки, Любовь).

Классификация Эконен отвечает задачам ее исследования, но мы, исходя из своих задач, хотим предложить иную рубрикацию. В частности, важно отметить, что любовь у Петровской имеет эпитет „Святая”. Эконен подчеркивает автономность Петровской от символистского контекста, которая нам представляется полемичной. Если для Белого (из стихотворения которого и пришло это выражение) „Святая Любовь” - явление, отдельное от низменной земной любви, то для Петровской „Святая” - постоянный эпитет: во всех своих проявлениях (в том числе и в земных) любовь сохраняет святость. 
Рассказы изображают различные, хотя в чем-то и сходные проявления Любви и психологии столкнувшегося с ней героя. Сходство ряда сюжетов можно объяснить символистским интересом к „оттенкам”, „вариациям” и „зеркальности”: похожие рассказы подсвечивают друг друга, намекая на потенциальное множество подобных ситуаций, и в то же время предполагают некоторый инвариант: платоновскую „идею” бесконечно реализуемого сюжета.

Сборник объединен не только на сюжетно-тематическом, но и на повествовательном уровне: во всех текстах повествование ведется от лица героя-рассказчика, чья стилистическая манера остается практически неизменной. Тождественность повествователя эксплицирует его служебную функцию: он интересен не сам по себе, а как тот, кого коснулась Любовь.

В связи с использованием мужского „голоса” важно отметить и устойчивую тему „переодевания” в посвященных друг другу текстах Петровской и Ауслендера. Так, в первом посвященном Петровской рассказе Ауслендера Корабельщики, или Трогательная повесть о Феличе и Анжелике („Весы”, № 11, 1907) героиня (в которой, на наш взгляд, ведется игра с образом Петровской), попав на корабль, притворяется мальчиком-пажом, что может быть дополнительной отсылкой к повествовательной манере писательницы, уже опубликовавшей множество своих рассказов в периодике. В то же время, в петербургских письмах к Брюсову Петровская называет Ауслендера „маленьким мальчиком” и „девочкой”. К этому следует добавить игровую „мужскую” подпись Петровской под письмами к Ходасевичу - „Ваш Нин.”

Несмотря на гендерное различие эпистолярного и художественного повествователя, при сопоставлении рассказов и писем Петровской обнаруживается множество параллелей. Елена Тырышкина полагает, что „в искренности и нелитературности этих писем трудно сомневаться” (Tyryškina 141). В то же время письма Петровской настолько же „литературны” (изысканны), насколько ее рассказы, и скорее свидетельствуют о симбиозе литературной и жизненной сфер писательницы. Такое проникновение поведенческих моделей и целых сюжетов из литературы в жизнь (в письма) и обратно в литературу подтверждает нашу гипотезу о жизнетворческом характере книги Sanctus Amor.

Приведем два примера параллелей между отрывками из письма Петровской Ходасевичу от 11 мая 1907 года и фрагментами ее прозы (первый подмечен Щербаковым и Муравьевой, второй - нами): 


\begin{tabular}{|c|c|}
\hline Из письма Нины Петровской & Из рассказа Нины Петровской \\
\hline $\begin{array}{l}\text { Есть весенние (души - А. С.), я их ню- } \\
\text { хаю, как те цветочки на тоненьких нож- } \\
\text { ках, что вырастают на первых проталинках } \\
\text { (Ŝerbakov, Murav'eva 377). }\end{array}$ & $\begin{array}{l}\text { У вас душа, как весенний цветок. Знаете, } \\
\text { те желтые цветочки на тоненьких нож- } \\
\text { ках, что вырастают на первых проталинах } \\
\text { (Petrovskaâ 92). }\end{array}$ \\
\hline $\begin{array}{l}\text { Ах, хочется [...] чтобы туда приехал „мой } \\
\text { милый” из Скандинавии. У него глаза си- } \\
\text { ние, а душа обречена Любви и смерти. При- } \\
\text { дет ли он? Боже мой, неужели не придет? } \\
\text { (Ŝerbakov, Murav'eva } 378 \text { ). }\end{array}$ & $\begin{array}{l}\text { Она, та, которую жду я всю жизнь, - она } \\
\text { придет! }[\ldots] \text { У нее }[\ldots] \text { в глазах цветет лю- } \\
\text { бовь и синяя глубь суровых фиордов }[\ldots] \\
\text { ничего, кроме любви }[\ldots] \text { Она придет! Она } \\
\text { придет (Petrovskaâ } 15-18) \text {. }\end{array}$ \\
\hline
\end{tabular}

В письме Петровская описывает свое эмоциональное состояние и ближайшие планы: „Вечер, одиночество, май. Сердце горит. Сейчас придет один Прохожий, о котором я Вам однажды расскажу" (Ŝerbakov, Murav'eva 378). „Прохожими”, по словам Ходасевича, она называла мужчин, с которыми заводила „мимолетные романы” в ожидании Брюсова (Hodasevič 16). Брюсов - синеглазый „милый из Скандинавии”; „Прохожий” - приземленная личность, поглощенная „заботой о днях” и „лукавым и мелким расчетом”. Возможно, скандинавский контекст образа Брюсова связан в сознании Петровской с романом Гамсуна Пан (воспоминания героя о „северном лете” в Норвегии и Любви). Отсылки к этому произведению не раз встречаются в рассказах Петровской (ср. описание Эдварды, ожидающей возлюбленного, глазами доктора):

Я видел, как она ломала руки в ожидании того, кто должен был прийти и взять ее, увезти ее отсюда, властвовать над ее телом и душой. Да. Но он должен явиться извне, вынырнуть в один прекрасный день, как совершенно особенное существо (Gamsun 71).

В схожей ситуации находится герой первого рассказа (Она придет), проводящий бессонные ночи в ожидании настоящей любви и одновременно знающий, что к нему „скоро придет женщина”, его любовница („прохожая”). Женщина сообщает герою о возвращении мужа и скорой разлуке. Когда же он излагает гостье свое представление об идеальной любви (см. табл. выше), она обнаруживает „приземленность” и неспособность понять его:

Я должна бросить мужа, должна думать о тебе и день и ночь, до рассвета страдать у твоих окон... Что должна я делать еще? Но ты забываешь, что кроме любви есть еще жизнь (Petrovskaâ 16).

Противопоставление „любви” и „жизни”, их взаимная несовместимость - один из лейтмотивов сборника, особенно ясно сформулированный 
в рассказе Бродяга, героиня которого покидает героя, как только он решается сделать ей предложение руки и сердца:

Ну посмотри, - разве я жена! [...] Вот мы больше не встречаемся в этой комнате, а живем где-то вместе, и я твоя жена. У нас несколько больших комнат и общая спальня [...] мы раздеваемся равнодушно и бесстыдно [...] словно неизлечимая болезнь, жизнь входит в те неотвратимые сцепленья, что люди называют „обычными нормами” [...] у нас второй ребенок. Я полнею [...] за мной ухаживают твои приятели. [...] Ночью я встречаюсь с твоим виноватым взглядом и делаю вид, что сплю [...] Что сделали мы с любовью? - спрошу я тебя однажды и увижу в твоих глазах тупую покорную тоску (Petrovskaâ 66-68).

В воспоминаниях Петровская демонстрирует схожее мировоззрение, отмечая такие свои черты, как „оторванность от быта и людей, почти что ненависть к предметному миру", что отмечал и Брюсов (Garetto 56). В то же время, она стремилась реализовать литературную модель идеальной любви на собственном опыте:

Совместить эти два пространства (искусства и реальности - А. С.) она не могла (хотя и пыталась воплотить в жизнь эстетическую утопию великой Любви), а отречься от этой утопии была не в силах (Tyryškina 136).

В тех же воспоминаниях Петровская отмечает, что не смогла бы взять на себя обязанности по устроению быта даже с Брюсовым:

Да, я, конечно, не могла бы играть с ним и его родственниками по воскресеньям в преферанс [...] чистить щеткой воспетый двумя поколениями поэтов черный сюртук, печь любимые пироги, варить кофе по утрам, составлять меню обеда и встречать его на рассвете усталого, сонного, чужого (Garetto 60).

Отказываясь от „обычных норм” жизни во имя Любви, Петровская наделяет ее традиционно-поэтическим качеством „безумия”, что встречается в ряде текстов на уровне мотива. Приведем только самые показательные случаи. В рассказе Она придет героиня упрекает в безумии героя-мечтателя:

Если ты ждешь кого-то еще, значит ты не любишь меня. Или от одиночества и праздности у тебя такие безумные мысли? [...] Тобой завладело безумие [...] Опомнись!.. Разве есть на свете такая любовь! (Petrovskaâ 14-16).

В рассказе Весной, когда герой в январе чувствует приближение весны и „ее нежную поступь”, над ним „смеются как над безумным”, а когда в толпе ему мерещится возлюбленная, его сердце „безумно” вздрагивает (Petrovskaâ 36, 39). В рассказе Я и собака герой безответно влюблен и готов „в светлое безумие ожидания превратить всю свою жизнь” (Petrovskaâ 54). 
Наконец, героиня рассказа Бродяга с предельной ясностью формулирует семантическую близость „любви” и „безумия”, противопоставляя этот смысловой комплекс „жизни” и „быту”:

Моя любовь то, что называют „безумием”. Эта бездонная радость и вечное страдание. Когда она придет, как огненный вихрь, она сметет все то, что называется „жизнью” (Petrovskaâ 62).

Щербаков и Муравьева отметили значимость мотива „безумия” и в рецензии Петровской на книгу Станислава Пшибышевского Заупокойная месca (1893; пер. 1904):

трагическое безумие, проявляющееся [...] в различных формах, которые условно [...] называют видами неврозов и психозов, вскрывает невидимую жизнь души и выявляет в мгновенной вспышке молнии все, что есть в ней глубокого и тайного (Ŝerbakov, Murav'eva 387).

По мнению исследователей, Петровская и „свои отношения с Брюсовым [...] пыталась построить как «трагическое безумие», без быта, в абстрактном пространстве" (Ŝerbakov, Murav'eva 387), как видим, не разграничивая литературу и жизнь.

Помимо семантики „любви - безумия” и гендерных игр с прототипами, в книге Петровской важную роль играет календарная символика: она скрыто присутствует во всех рассказах, а в двух из них выносится в заглавие (Осень и Весной). На основании повторяемости элементов (сюжетно-тематических и пространственно-временных) мы вслед за Эконен, но несколько иначе, выделяем четыре группы рассказов сборника:
А) Она придет (№ 1) и Я и собака (№ 5).
- Ожидание Любви.
Б) Ложь (№ 2), Весной (№ 4), Бродяга (№ 6).
- Встреча с Любовью.
В) Раб (№ 3) и Северная сказка (№ 7).
- Предательство Любви.
Г) Призраки (№ 8), Осень (№ 9), Любовь (№ 10). - Смерть.

Если каждую категорию маркировать буквой и выстроить рассказы последовательно, получится такой порядок:

$$
\begin{array}{llll}
\text { Она придет (А) } & - \text { Ложь (Б) } & - \text { Раб (В) } & - \text { Весной (Б) } \\
\text { Я и собака (А) } & - \text { Бродяга (Б) } & - \text { Северная сказка (В) } \\
\text { Призраки (Г) } & - \text { Осень (Г) } & - \text { Любовь (Г). }
\end{array}
$$

Заметно, что сначала Петровская стремится чередовать типы, и это задает цикличность в пределах первых семи рассказов, где встречаются три 
разновидности (ожидание - встреча - предательство), но на третьем „витке” вводится новый тип, который повторяется трижды. Такая цикличная последовательность с установлением тенденции и ее нарушением на третьем витке чрезвычайно напоминает структуру лирического стихотворения (в классической трактовке Бориса Томашевского). Не исключено, что такой композиционный прием призван подчеркнуть лирический характер сборника „песен любви”.

Рассмотрим теперь выделенные нами категории рассказов по отдельности.

А) Она придет (№ 1) и Я и собака (№ 5). В первую группу мы объединили два рассказа, оставив за ее пределами предложенный Эконен рассказ Весной, поскольку в нем происходит соединение героя и героини, а значит „ожидания мужчины” оказываются не такими уж „нереалистическими”. В обоих рассказах группы действие происходит осенью (20 сентября и в ноябре), а окружающий героя пейзаж подчеркивает безнадежность его ожидания настоящей любви. Так, в первом рассказе природа подсказывает ему безрадостные мысли, хоть он и относится к ним „с улыбкой”:

Маленькие серые мошки [...] ползают по рукам. Скоро, скоро [...] многие из них умрут от первого утреннего мороза, и ветер понесет неизвестно куда их маленькие холодные трупы. Думаю о них. О странно короткой жизни, черпающей силы из солнечного луча, о их покорной, молчаливой смерти, и улыбаюсь черным движущимся точкам (Petrovskaâ 7).

В рассказе Я и собака пейзаж не сельский дневной, а ночной городской, однако атмосфера его также пронизана мрачными думами героя:

Ждем ее - я и собака. Дрогнем в ноябрьском тумане - две жалкие черные тени [...] В поздний час в конце бульвара меркнет желтый четырехугольник кафе. Кто-то [...] гасит длинную цепь фонарей, и над нами опускается серый безрадостный мрак (Petrovskaâ 45-46).

Инвариантная ситуация обоих рассказов - „идеальное ожидание идеальной любви”. В первом рассказе (Она придет) герой проводит бессонные ночи в ожидании, но вместо идеальной возлюбленной к нему приходит замужняя любовница. Диалог героев, на наш взгляд, отсылает к аналогичной сцене из романа Гамсуна Пан, но с важным отличием. Ср.:

\begin{tabular}{|l|l|}
\hline \multicolumn{1}{|c|}{ Она придет } & \multicolumn{1}{c|}{ Пан } \\
\hline Вот она подходит к калитке. Идем на балкон, & Она шла мне навстречу с горячим румянцем \\
садимся на ступеньках. & на щеках, и все ее лицо сияло. \\
- Я ждала тебя вчера, - говорит она с легким & - Вы ждали? - сказала она. - Я боялась, что \\
упреком. - Почему не пришел? & вам придется ждать. [...] \\
\hline
\end{tabular}




\begin{tabular}{|l|l|}
\hline - А это не ты приходила к моим окнам & - Кто-то был у моей хижины ночью? - сказал \\
ночью? - спрашиваю я. & я: - я видел утром следы на траве. \\
- К твоим окнам? Ночью? - удивляется & Ее лицо густо окрашивается, она берет меня \\
она. - Что за странные у тебя мысли? Зачем & за руку тут же на самой дороге и не отвечает. \\
бы пришла я к твоим окнам? Вчера, ожидая & Я смотрю на нее и спрашиваю: \\
тебя, я укладывала вещи - ведь завтра мы & - Быть может, это были вы? \\
едем. А ночью вернулся муж (Petrovskaâ 13). & - Да, - отвечала она и прижалась ко мне: - \\
& это была я. Я вас не разбудила, я подошла \\
& так тихо, как только могла. Да, это была \\
& я. Я была близко к вам еще один раз. Я вас \\
& люблю (Gamsun 39$).$ \\
\hline
\end{tabular}

Очевидно, герой Петровской ожидал именно того ответа, какой получил герой Пана. Получив приземленный ответ, он переживает это как „подмену”: „Ты не та, - вот и все. Она могла бы иметь твое лицо, твои прекрасные глаза, твой нежный, умный лоб, но пришла все же не она, а ты" (Petrovskaâ 15). Оскорбленная любовница уходит, а герой погружается в „неспешные волны набегающих мыслей” об идеальной возлюбленной. В конце рассказа дан намек на то, что чаяниям героя не суждено сбыться на земле: „Ночь с извечной печалью прильнула к земле и шепчет черными губами: придет!.. после смерти" (Petrovskaâ 18).

В ряде рассказов сборника присутствуют эротические эпизоды, но в рассказах этой группы они не встречаются. В отличие от рассказа Весной, герои здесь не предаются физической близости, даже несмотря на то, что являются любовниками. Это, на наш взгляд, подчеркивает мечтательно-идеализированный образ героя и тему „ожидания” Любви.

В рассказе Я и собака герой вместе со своим псом Локи „четвертую ночь” ожидает женщину в холодном и сыром „ноябрьском тумане”. Примечательно, что герой романа Пан также владелец собаки, Эзопа, бывшей его „единственным товарищем" (Gamsun 10). Имя собаки в настоящем рассказе отсылает к стихотворению Брюсова, связанному с Петровской (Бальдеру Локи), а образ собаки в этом контексте - к множественным зооморфным метафорам, возникающим при портретировании Брюсова в текстах его современников.

Герой бодрствует ночью, а днем предается туманным переживаниям: „Дни исчезают. Я не знаю, куда деваются дни. Может быть, сплю я днями, и мне видятся странно-блаженные сны” (Petrovskaâ 46). Как и в первом рассказе, последние строки вводят тему вечного ожидания:

мы будем ждать ее и сегодня, и завтра, и всегда. В светлое безумье ожиданья превращу я всю мою жизнь. Может, быть, она вернется, может быть, туда, где дико ликует пьяная страсть, холодным, нежным облаком приникнет к изголовью моя покорная любовь [...] Может быть, Локи? (Petrovskaâ 54-55). 
Но есть и различие: во втором рассказе герой ждет уже не идеальную, а конкретную женщину, некогда отвечавшую ему взаимностью, но охладевшую (раздвоенная героиня первого рассказа объединяется в одну фигуру). В одну из ночей она приходит и пренебрежительно сообщает герою, что отправляется на бал. Не выдержав одиночества, герой отправляется за ней и на балу наблюдает, как „кто-то высокий и стройный уверенным движением обнимает ее талию”, а также замечает ее лицо - „бледное, с слишком алыми жадными губами, со знакомым выражением в опьяненных счастьем глазах" (Petrovskaâ 51). „Презрительная усмешка женщины”, ее „жестокие нежные руки в сверкающих кольцах”, „слишком алые жадные губы” соответствуют типу femme fatale и женщины „вамп”, что позволяет рассмотреть героиню в контексте „вампиризма”, подмеченного Эконен в рассказе Призраки, который занимает схожую позицию на третьем „витке” композиции сборника. Заговорив с женщиной, герой убеждается в ее безразличии и, вернувшись домой, парадоксально предается безнадежно-идиллическому ожиданию (неожиданный пуант).

Объединяют героев и мысли о смерти. Перед тем, как отправиться на бал, герой пятого рассказа примеряет перед зеркалом черный сюртук и думает: „Черные сюртуки так сидят на покойниках [...] А надевают мертвым белые галстуки? Совсем не знаю, принято ли надевать им белые галстуки?” (Petrovskaâ 51). Вернувшись с бала, он предается совсем уже горестным размышлениям: „Я так одинок, что, если я умру сейчас, то завтра никто не вспомнит моего имени" (Petrovskaâ 54).

Впрочем, мотив смерти в том или ином виде встречается во всех рассказах сборника и наряду с „безумием” входит в семантический ореол Святой Любви. По замечанию Александры Хван, „особая связь любви и смерти, мистическую близость которой ощущали все творцы «серебряного века» раскрывается в оппозиции Божественного/земного, которая определяет трагичность конфликта любви с миром обыденным" (Hvan 89).

Своего рода „оппозицию Божественного/земного” представляют и первые два рассказа - через двойственность образа „идеальной любви”. В первом случае - это воображаемая женщина, наделенная чертами „Вечной Женственности” и „Прекрасной Дамы” (Иоганна Вольфганга Гете, Владимира Соловьева, Александра Блока и пр.), во втором случае - ее земное отражение, воплощенное в образе роковой женщины. Подобные трансформации, заметим, происходят с земными воплощениями „небесных” героинь и у Блока, например. Можно говорить о парности этих сюжетов, „идеальной” и „земной” реализации сюжета вечного ожидания.

Б) Ложь (№ 2), Весной (№ 4), Бродяга (№ 6). Если для первой группы характерно отсутствие контакта с Любовью (или ее воплощением), то для 
второй - общим будет случайная или мимолетная встреча (контакт), приводящая к различным последствиям.

Действие происходит зимой, однако второй рассказ называется Весной: во внешнем мире царит январь, но в душе героя уже наступила весна. Возможно, „межсезонный” характер рассказа обусловил его пограничное положение между первым и вторым „витками” композиции.

Рассказ Ложь начинается с риторического обращения к отсутствующей женщине: „Кто ты? Я видел тебя два раза и не знаю, была ты или приснилась" (Petrovskaâ 19). Далее излагается история отношений. После первой встречи герой провожает героиню домой, предварительно взяв у нее адрес и договорившись о новом свидании. Героиня формулирует одно из правил центрального для сборника концепта Святой Любви:

Не надо спрашивать. Нужно покорно приближаться к любви. Мы так мало любим. Встречаемся и уходим, может быть, навсегда [...] Посмотри мне в глаза. Вот так. Сегодня нас поцеловала судьба (Petrovskaâ 21-22).

Теме любви в большинстве рассказов сборника сопутствуют мотивы „звучания/музыки/рассказа”. Вторая встреча происходит в гостиничном номере, где герои предаются любви, переданной с помощью звуковых образов, отчасти в манере Блока:

Волосы твои что-то пели, прикасаясь к щеке. Что это? Откуда? „Не знаю... Это музыка” [...] бубенчики звенят точно вдали [...] твои поющие нежные руки ласково легли на захолодевший лоб [...] О чем-то простом и ясном рассказывают ласковые пальцы [...] Постой. Тише. Слушай музыку. Вот звенящие волны отделяются от твоего тела. Рассказывают о тебе (Petrovskaâ 20-24).

Здесь и в других рассказах умение слышать зов Любви среди повседневного шума будет маркировать персонажа, которому суждено встретить Любовь или который, по крайней мере, способен к ее восприятию. Но эта встреча мимолетна: герой возвращается домой, в унылый семейный мир. Так заканчивается первая история о мимолетной встрече героя с Любовью, воплощенной в случайной женщине.

Если герои рассказов первой группы переживают ситуацию расставания с меланхоличной обреченностью, то герой Лжи оптимистичнее: „Уедешь, а светлая солнечная полоса надолго протянется за тобой. Буду смотреть тебе в след с тихой благодарностью" (Petrovskaâ 24). Следует указать и на возможный биографический подтекст этого рассказа. В своих воспоминаниях Петровская пишет о том, как в начале романа с Брюсовым (,это было в начале декабря”) он отвез ее в номер гостиницы „Русь”: 
Маленькая узенькая комната [...] Гиацинты на этажерке, на подзеркальнике [...] низкое глубокое плюшевое кресло [...] Мне кажется, что вытертый на ручках плюш был зеленый с розовыми веночками [...] Никогда не забуду этого ощущения под пальцами, уже интимного, незабвенного уже (Garetto 70-71).

Гостиничный номер из рассказа в общих чертах напоминает описанный выше, но текст рассказа отличается подчеркнутой идилличностью. Следует добавить, что рассказ Ложь был впервые опубликован в сборнике стихов и прозы Корабли (1907), в котором был напечатан и рассказ Ауслендера Бастилия взята.

Рассказ Весной тоже приурочен к зиме, но герой живет по собственному календарю, в котором „весна всегда приходит в январе” (Petrovskaâ 36). Каждую весну „странный обман овладевает душой” героя, и когда „колокола поют нежными серебряными голосами”, он отправляется на улицу в надежде встретить ушедшую три года назад женщину, чей портрет он хранит (Petrovskaâ 37-38).

Отметим чуткость героя, способного „уже после нового года в слишком алых закатах” разглядеть „воскресающий лик” весны и распознать особую музыку колокольного звона. Активность поисков вознаграждается: в одну из прогулок к герою подходит женщина - носитель знания о Святой Любви. Пребывая, подобно герою, в „весеннем” состоянии духа, женщина формулирует свое кредо:

Весной хочется умереть, - говорит она. Самое жестокое и горькое вспоминается весной вы замечали? [...] Какая тоска! [...] Нужно жить, чтобы от каждого мига где-то расцветали цветы [...] Нужна ласка, ласка [...] Не твоя ко мне, не моя к тебе. Не знаю, чья - все равно. Ласка и нежность, как дар нашей неведомой судьбы [...] если она не будет приходить, нас злобно стиснут стены, задушат улицы, нас убьет одиночество, и нашего крика не услышит никто (Petrovskaâ 41-43).

В словах героини о том, что „весной хочется умереть”, что „самое жестокое и горькое вспоминается весной” слышны автобиографические ноты. 29 апреля 1907 года Петровская писала Ходасевичу: „В апреле и мае я почему-то всегда страдаю. Весна меня не приемлет, а я еe” (Ŝerbakov, Murav'eva 373). В призывах и предостережениях героини содержится контрастная отсылка к героям первой группы рассказов, которые не предпринимают активных шагов для „приближения к любви” или „ласке и нежности”. Героиня приглашает героя к себе, и вновь „звучит” любовная тема:

$[\ldots]$ тонкие волосы $[\ldots]$ договаривают что-то печальное и важное $[\ldots]$ поют печальные мелодии [...] что-то пронзительно-грустное, как надорванная струна, звенит в незнакомой комнате [...] Немо, беззвучно, томительно длинными поцелуями рассказываем друг другу трагедии своих одиноких дней (Petrovskaâ 43-44). 
Затем женщина замечает, что „должно быть, поздно”, и герой уходит. На этот раз он не женат, но и у него есть „другая женщина” - это утерянная три года назад любовь, чей портрет он хранит: „Точно из гроба, смутно выступает высокий лоб, потемнели и впали глаза" (Petrovskaâ 37).

Портрет представлен в виде „умершей”, которая не отпускает героя-повествователя, обрекая его на „идеальное ожидание”, свойственное героям рассказов первой группы. Случайная встреча помогает ему преодолеть это состояние. Возможно, он ошибается, приписывая ежегодное „весеннее” предчувствие мыслям об утраченной любви; его чуткая натура слышит весенний зов живой Любви.

Рассказ Бродяга завершает цикл о мимолетной встрече с Любовью и окончательно проясняет сквозную идею этой группы. Действие происходит зимой, герой повествует о своем кратковременном счастье - встречах с женщиной в течение двух лет. Они познакомились за столиком, в утренний час и героиня открылась герою: „Я думаю о любви [...]. Всегда о любви. Смотрю в глаза, угадываю темные тайны душ, слушаю мелодии голосов” (Petrovskaâ 59). Ее причастность стихии Любви подтверждается рядом реплик:

Трудно угадать, кого уже отметила любовь [...] Я бродяга, скитаюсь по душам и все жду встречи с той любовью, что вижу только во сне [...] Моя любовь то, что называют „безумием". Эта бездонная радость и вечное страдание. Когда она придет, как огненный вихрь, она сметет все то, что называется „жизнью”. В ней утонет все маленькое, расчетливое, трусливое, чем губим мы дни. Тогда самый ничтожный станет богом и поймет навсегда великое незнакомое слово „беспредельность” [...] Тебе больно? Ты плачешь? [...] Так нужно. Так суждено всем, полюбившим Любовь... (Petrovskâ̂ 59-69).

После двух лет счастья герой „не выдержал остроблаженных мук” и предложил героине стать его женой. Ее ответ мы приводили выше: брак погружен в быт, который убивает любовь. Поэтому она отказывается, напутствуя на прощание своего любовника и ученика: „Мы оба узнали многое. Предстоит идти еще дальше, еще выше. Ты поймешь это после, без меня" (Petrovskaâ 65-66). Таким образом, для героини наиболее важным оказывается не герой как объект любви, а сама Любовь, вернее - ее первая, самая пленительная и волшебная стадия:

Ее глаза широко раскрылись и загорелись, как огромные, черные камни. Губы изогнулись в истомленно-жадной улыбке, точно хотела она выпить, как острое душистое вино, всю мою душу, весь трепет первой мучительной страсти (Petrovskaâ 62-63).

Cp. с описанием Ауслендера в Венеции из письма Петровской от 7/20 марта 1908 года: 
Будет ли он настоящим - не знаю. Должно быть, нет. Но эту душу я возьму, я так хочу. Я увижу ее холодно всю до конца (Brûsov, Petrovskaâ 259-260).

Несмотря на кажущуюся близость теме „вампиризма” (выпить душу), героиню нельзя отнести к описанным в рассказе Призраки людям, лишь притворяющимся живыми: она не опустошает, а наполняет жизнью. Она выступает в роли служительницы или жрицы Любви, одновременно посвящая в этот культ героя, и мы догадываемся, что он - не единственный неофит. О том, насколько серьезно герой воспринял учение, можно судить по финальной сцене: он вспоминает, что на прощание, „как ученик, узнавший большую сокровенную тайну [...] поцеловал ее ноги в маленьких черных туфлях", и с тех пор „она не одна идет своей вечной дорогой. Мы далеки, но вместе. Мы вдвоем чутко слушаем вечно призывающий голос Любви" (Petrovskaâ 69).

Герои рассказов настоящей группы оказываются облагодетельствованными мимолетным прикосновением Любви и остаются благодарными за этот дар. Герой последнего рассказа удостаивается чести стать служителем Любви, проникнуть в тайны ее культа. Следует добавить, что в Бродяге присутствует указание на то, что героиня замужем: „Иногда я видел ее мужа всегда мрачного молчаливого человека. Иногда слышал какие-то странные рассказы о их жизни" (Petrovskaâ 56). Однако это не мешает ей посвятить свою жизнь Святой Любви.

В) Раб (№ 3) и Северная сказка (№ 7). В третью группу мы объединили два рассказа, которые схожи сюжетно, хронотопически и прототипически. В июне 1905 года Брюсов с Петровской отправились в Финляндию, и это время, проведенное „в Гельсингфорсе и на озере Сайма $[. .$.$] осознавали$ и тогда, и впоследствии как самую знаменательную, самую счастливую пору

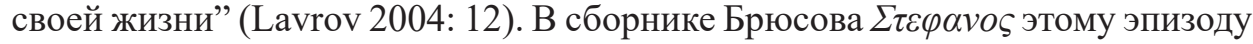
посвящен цикл На Сайме, состоящий из восьми текстов, насыщенных образами, которые встречаются в рассказах настоящей группы (голубые глаза, лодка, волны, сосны и т.д.). По замечанию Эконен,

саймский топос [...] стал популярным в русской литературе в 90-е годы XIX века [...] Началом традиции можно считать стихи, написанные В. Соловьевым [...] во время пребывания в Финляндии (Èkonen 286).

Рассказы данной группы образуют своего рода кульминацию макросюжета сборника, представленную двумя вершинами: в предпоследней позиции первого „витка” и в финале второго; в обоих случаях они занимают третью позицию от начала витка, сменяя рассказы группы А и Б. Их общая тема - „предательство Любви”. Кроме того, Северную сказку можно рассматривать и как продолжение рассказа Раб. 
В рассказе Раб герой приехал на два месяца в „маленький домик над тихим озером”, „когда зацветала сирень”, и поселился в „маленькой летней комнате” по соседству с „двумя финнами” и героиней рассказа (Petrovskaâ 26-27). Они познакомились в первый же вечер, и вскоре герой „слушал нежный, незнакомый голос, смотрел в непонятно дорогое лицо, и казалось ему, что ласковые, свежие пальцы тихо касаются его темного сердца, никогда не знавшего счастья" (Petrovskaâ 28-29).

Спустя два счастливых месяца герою пора возвращаться домой, к жене, десятилетняя жизнь с которой „была тяжелым подвигом, вечной тоской по [...] незнакомой женщине с печальными глазами" (Petrovskaâ 29). Несмотря на предчувствие, что „вся жизнь его вновь сожмется роковым безысходным кольцом", герой все же не решается написать жене прощальное письмо и, таким образом, „беззаботной рукой убить маленькую женщину с ее ненужной десятилетней любовью" (Petrovskaâ 30, 33).

В описании ночи перед расставанием вновь возникает мотив „присвоения души”: „Я твой, возьми мою жизнь, мою душу” (Petrovskâ̂ 32). Однако слова остаются словами: герой покидает героиню - предает Любовь, и потому его образ сопоставляется с образом вора („,около сложенных вещей стою я, как вор”, „вдоль темных заборов я еду, как вор”) и даже убийцы: во время прощания герой думает, что в его глазах, „как в зрачках убийцы, навсегда запечатлеются дрожащие белые пальцы” (Petrovskaâ 29-30, 32, 33). Этот образ преследует героя и по его возвращении домой, где все осталось так же, как „было десять лет назад” и „будет всегда”: увидев жену, ему захотелось

медленно сдавить пальцами упругую белую шею, долго смотреть в помертвевшие от ужаса глаза, потом бросить ее, обезумевшую, дико захохотать, закружиться по комнате в белой, короткой рубашке и все хохотать, хохотать... (Petrovskaâ 34-35).

Однако он не осуществляет ужасного наваждения и, засыпая с женой, думает о своем бездушии: „Я кукла” (Petrovskâ̂ 35). Убив Любовь, герой и сам душевно умирает. Эконен обратила внимание на то, что в рассказе Призраки

рассказчик и другие персонажи являются живыми трупами, картонными куклами, манекенами [...] кукла, картонная кукла, манекен, или восковой манекен, входят в словарь рассказов Петровской (Èkonen 273-274).

Действительно, лексема „кукла” встречается и в письмах. 27 сентября 1907 года, Петербург: „Пробыла весь день дома [...] сидела на диване как кукла” (Brûsov, Petrovskaâ 240); 12/25 марта 1908 года, Флоренция: „Часто, часто вспоминаю Финляндию, и тогда глубоко презираю эту гигиеническую 
поездку, и смеюсь мальчику в лицо, и говорю ему, что ты Единственный, Вечный, Любимый, навсегда, а он - кук-ла... (так назвал его Б. Н.), а он шутка, забава, игрушка с навеки испорченным механизмом" (Brûsov, Petrovskaâ 269-270); 13/26 ноября 1908 года, Лейпциг: „Во всем остальном, что называется теперь моей жизнью, я - механическая кукла, очень искусно имитирующая человека" (Brûsov, Petrovskaâ 338); вторая половина ноября-декабрь 1910 года, Москва: „Ах, неужели тебе бы не было жалко, если бы я стала совсем деревянным автоматом, веселой куклой, из которой вынули все пружины, мотающей головой куклой?” (Brûsov, Petrovskaâ 594).

Во всех случаях образ „куклы” наделяется схожими коннотациями: это - бесчувственный, бездуховный, „мертвый” человек, имитирующий жизнь. В чем-то схожие коннотации (безвольность, неспособность к самостоятельным действиям) содержатся и в заглавии рассказа Раб. В рамках текста „превращение” героя в куклу, конечно, обусловлено его предательством Любви, неспособностью совершить „безумный” поступок и вырваться из рабства противопоставленного ей мира „жизни” и „быта”. За это герою приходится поплатиться „жизнью” - не только своей, но, вероятно, и своей возлюбленной, так как в момент прощания они „несколько мгновений смотрят друг на друга” так, словно они „оба навсегда простившиеся с жизнью" (Petrovskaâ 33).

Вполне прозрачный намек на отношения с Брюсовым не является единственным ключом к пониманию текста. В сборнике он становится элементом макросюжета, адресованного Ауслендеру, и может рассматриваться как предостережение от предательства Любви с описанием возможной расплаты за вероломство. Предостережение отнюдь не избыточное, поскольку ни в прозе, ни в жизни Ауслендер не разделил с Петровской ее идеала Святой Любви: в повести Корабельщзики герой уклоняется от соединения с героиней, а в романе Последний спутник - покидает ее после итальянского „медового месяца" (равно как и в жизни).

Отметим также обыгрывание цветовой символики: когда герой приезжает в летний дом, он способен замечать цвета и оттенки:

Последний раз стою у окна [...] горько улыбаюсь соснам, гранитам и бледному небу, - голубоокой стране шлю печальную благодарность за отошедшие ясные дни [...] зацветала сирень, и на террасе чуть завивался нежно-зеленый, тонкий хмель [...] Целовать там розовые стволы тоненьких сосен, забыться в душистозеленом мраке [...] бледным золотом горела сапфирная вода. Золотые искры сверкали в черных волосах. Грустное лицо тихо розовело в бархатно-теплых лучах (Petrovskaâ 26-28).

Ср. синтаксис, интонацию и рассказчика, живущего в лесной сторожке на севере Норвегии, в романе Гамсуна Пан: 
Я лежу весь вечер и смотрю в окно, волшебный блеск покоился в это время на полях и лесах, солнце зашло и окрасило горизонт жирным, красным светом, неподвижным, как масло. Небо было совершенно безоблачно и прозрачно, я погружался взором в это ясное море [...] Бог знает [...] почему горизонт одевается сегодня в лиловое с золотом, уж не праздник ли там наверху во вселенной [...] с звездной музыкой и с катаньем в лодках по рекам (Gamsun 17).

По едкому замечанию Пильского, указавшего на влияние Гамсуна в рассказах Петровской, она „именно из его Пана списала больше половины своей Северной сказки" (Mihajlova 774). Действительно, некоторые эпизоды рассказа Петровской напоминают роман Гамсуна, в частности, цветовой восприимчивостью героя. Однако для героя Раба, вернувшегося к жене, палитра редуцируется до черно-белой гаммы, подчеркивая безжизненность бытового пространства героя: „белые рубашки”, „черный сюртук”, „белая шея” жены и траурные „черные сосны” (Petrovskaâ 34-35).

В Северной сказке представлена вариация на тему „предательства Любви", которую можно рассматривать как продолжение рассказа Раб. Рассказ начинается с характеристики Святой Любви, данной через слова героя, что сразу эксплицирует его причастность к этой стихии:

Мы ничего не знаем о любви. Когда она приходит, Бог знает откуда, мы видим лишь огненный меч, взнесенный над нашей жизнью, и с ужасом укрываем лицо. Боимся расстаться с маленькими радостями дней, не верим стихии, не умеем вовремя распахнуть ей все двери своего сердца [...] И за это любовь мстит нам, оборачивается грозным оскорбленным лицом и пророчит вторую встречу, от которой уже не укроет ничто (Petrovskaâ 70).

Предсказание второго пришествия Любви с огненным мечом намекает на конец света (с последующим возрождением), в чем (как и ниже, в мотиве „зорь”) можно усмотреть рудимент „аргонавтизма” Петровской, однако истолкованного иначе, чем у Белого, скорее в духе Вячеслава Иванова (апология страсти). К герою рассказа Любовь уже приходила: „в белые ночи короткого северного лета встретила [его - А. С.] на берегах бледного озера и запела свою единственную песнь" (Petrovskaâ 71).

В тот раз герой „не сумел распахнуть двери своего сердца”, и теперь, три года спустя, когда он живет с другой женщиной, Любовь приходит во второй раз и „пророчит новую встречу”. Поначалу герой не понимает, что слышит зов Любви: июньской ночью он видит во сне „северное озеро и розовую полосу двух обнявшихся зорь”, а затем, гуляя по городу, слышит „свистки парохода и чей-то настойчивый зов" (Petrovskaâ 72).

В ответ на зов Любви герой отправляется в загородный летний дом в Финляндии с „другой женщиной”. Его зрительная и слуховая восприим- 
чивость обострены: „голубыми глазами озер улыбается север”; „маленькие монетки звенели о чем-то непоправимом, но мы никогда не слушаем предостерегающих голосов вещей” (Petrovskaâ 72-73).

Способность героя слышать музыку или голос другого мира напоминает блоковские идеи о том, что „неустанное напряжение внутреннего слуха, прислушиванье как бы к отдаленной музыке есть непременное условие писательского бытия"1 (Blok 103). В рассказах Петровской это скорее - условие встречи с Любовью.

Приехав в то же место, где герой был три года назад, пара останавливается „в той самой комнате” (Petrovskaâ 73). Женщина радуется романтическому уединению, но героя одолевают мучительные воспоминания, и там, где она видит „зацветающую сирень”, ему кажется, будто „из цветников, из травы $[. .$.$] встают тихие тени и смотрят на него большими темными глазами"$ (Petrovskaâ 75).

Мрачное восприятие настоящего контрастирует с воспоминаниями, насыщенными звуковой и цветовой образностью - герой вспоминает, как на пристани пароход „белый, веселый, кричал пронзительно и громко, как молодой сильный зверь”; „озеро сверкало как сапфир”; ,желтобархатная пыль потоками струилась сквозь сосны, а озеро одевалось в голубые и желтые шелка" (Petrovskaâ 76). Герой пытается воскресить свои прошлые чувства, предлагая спутнице: „Слушай музыку вечера. Может быть, само солнце запоет сейчас старинную северную песнь, целуя воду алыми губами" (Petrovskaâ 76).

Но ее присутствие, вопросы и его собственные мысли о прошлом подавляют героя: хозяйка домика, фрау Шварц начинает казаться ему „седым призраком”, а приехавший „высокий англичанин” представляется „худым, как скелет". Вскоре он не выдерживает и рассказывает спутнице свою историю, она убегает, а он становится на колени и, глядя, как ,две зари целуют остывшую воду”, шепчет: „Я вновь с тобой. Я вернулся” (Petrovskaâ 85). Так реализуется заданная в первых строках тема мести Любви с огненным мечом. Жестокость героя по отношению к спутнице объясняется одержимостью этой стихией: „О, ты еще не знаешь, что в любви нет состраданья!” (Petrovskaâ 85).

Отметим, что в этом рассказе возникает и персонифицированный образ антагониста любви - ,загадочного бога жизни”: герой задается вопросом,

${ }^{1}$ О перекличках дебютного рассказа Петровской Она (1903) с Незнакомкой (1906) Блока см. Èkonen 280. Возможно, сходство здесь обусловлено не только общностью культурной среды, но и общими литературными корнями (в том числе связью с наследием Владимира Одоевского). 
почему он не смог уберечь любовь с первой встречи, и сам отвечает: „спросите у загадочного бога жизни, который бесстрастно смотрит с холодного неба" (Petrovskaâ 71). За два месяца до публикации рассказа Петровская использует схожий образ в письме к Ходасевичу (11 мая 1907 года): „Воистину, жизнь чья-то «ядовитая выдумка» [...] чертова игрушка и грустный смех загадочного Бога жизни" (Ŝerbakov, Murav'eva 378).

В дихотомической четкости противопоставления бога мещанской жизни и ревностной Любви ощущается влияние бунтарских религиозных „исканий” эпохи символизма. Здесь могло сказаться и неприятие (переворачивание) розановских схем, и „манихейский идеализм” Федора Сологуба (определение Дмитрия Святополка-Мирского), и отзвуки ницшеанства. Так или иначе, Любовь приобретает иномирный характер, противоположный жизни.

В обоих рассказах этой группы герой встречает Любовь, но предает ее, после чего, в рассказе Раб, он возвращается к семейному быту, а в Северной сказке, напротив, открыто порывает с ним: реализуется эсхатологическая модель сюжета - смерть и новое воскресенье. На этой высокой мистической ноте основная часть композиции завершается, и характерно, что кульминация приходится на седьмой рассказ. Примечательно, что самый „мистический” из рассказов оказывается и самым автобиографическим, изобилующим перекличками с эпистолярными текстами Петровской. Центральный для сборника образ святой Любви дополняется в этой группе мотивами возмездия (в очередной раз мы сталкиваемся с квазиблоковскими клише у Петровской). Обратимся к последней группе рассказов.

Г) Призраки (№ 8), Осень (№ 9), Любовь (№ 10). Рассказы последней группы собраны вместе и вынесены как бы в эпилог. Календарный принцип здесь несколько сбивается (весна-осень-осень), местом действия является город, но в конце герой оказывается за городом. Рассказы объединены темой смерти. Она встречается во всех рассказах сборника, но для этой группы мотив смерти становится центральным, а в последнем рассказе - сюжетообразующим. Видимо, в общей композиции книги все, что идет после седьмого рассказа, живописует „страшный мир” посмертного существования.

В рассказе Призраки герой делит людей на живых и призраков. Последних в мире больше, и они „художественно имитируют живую жизнь”, действуя „лишь по инерции, по механически усвоенной привычке”, „блестяще комбинируя обветшалый материал умершей души" (Petrovskaâ 86-87). Призраки „больше всего боятся смерти”. Иногда они испытывают „нестерпимое бесформенное страдание" и тогда, „закрыв маской лик холодного ужаса”, идут к живым, чтобы „напиться крови чужого чувства” (Petrovskaâ 90-91). 
Вероятно, образ восходит к одноименной повести Ивана Тургенева и, возможно, Балу Одоевского. Ср. также схожее определение людей, чьи „сердца окаменели в самолюбии” у Николая Минского (При свете совести, 1889):

из них каждый отдал бы полжизни, лишь бы полюбить что-нибудь кроме себя, но это невозможно; [...] над людьми уже отяготело проклятие [...] питать свое тело мертвечиной других тел, а свою душу - унижением других душ и при этом притворяться любящими (Minskij 21).

Сам герой-повествователь тоже относится к категории призраков, и это первый рассказ, в котором встреча с любовью оказывается для него органически невозможной. Тем не менее, ведомый своей вампирической жаждой, он отправляется на праздник, лживыми признаниями соблазняет женщину, входит в ее дом и пытается вызвать в ней чувство. Все это предвосхищает образность будущего Страшного мира Блока.

Отметим звуковую образность встречи героев: неспособный слышать призывы любви, герой обращает внимание на какофонию звуков: звук падающих с крыш капель, плач ребенка и музыкальное исполнение из Кармен (еще один „блоковский” мотив). Он не способен к гармонии: „[...] я стану кричать бессловесным сдавленным криком. Может быть, из груди моей вырвется протяжный звериный вой” (Petrovskaâ 96).

Бессилие героя проявляется и в том, что он не способен отличить живую женщину от „мертвой”: ему не удается вызвать в женщине живых чувств, поскольку и она оказывается призраком. „Безжизненная белизна” ее лица сравнивается с „лицом куклы”, а когда она „ударяет себя в грудь”, герою „слышится стук в пустой деревянный ящик” (Petrovskaâ 97).

Аналогичные образы встречаются и в письмах к Брюсову. 23 мая 1906 года она пишет ему из Варшавы: „Но я «Кук-ла», «Кук-ла»... «Кукла»... При этих словах в груди пустой и звонкий стук" (Brûsov, Petrovskaâ 179). 17 июня 1906 года из Лидино:

кто-то отнимает от меня мою живую жизнь, и я превращаюсь в призрак, которому стыдно, и страшно, и больно с живыми [...] Зачем встаю, зачем начинаю день? Чтобы преодолевать страх смерти. Животный, звериный страх от мысли, от ощущенья близости смерти (Brûsov, Petrovskaâ 205).

Если в письмах это еще - метафора, пусть и развернутая, то в рассказе метафора разрастается до мистическо-символического сюжета.

После неудачи герою „хочется хохотать громким циническим смехом и стучать палкой в холодные стекла занавешенных окон”, крича: „Проснитесь! Сама смерть идет мимо вас"; но вместо этого он напевает слышанный 
недавно мотив из Кармен. История Кармен заканчивается типовым для романтической цыганки образом - трагически. Полагаем, что отсылка к Кармен подготавливает единственное в сборнике убийство, совершенное в последнем рассказе. Кроме того, обращение к избитому мотиву подчеркивает „глухоту” героя к подлинному зову Любви.

Это единственный рассказ в сборнике, где любовь отсутствует на сюжетном уровне. Смерть же представлена метафорически (или символически) - как невозможность испытывать живые чувства: в контексте книги это воспринимается как наиболее страшная участь для человека.

Петровская словно предвидит многие образы Блока, Марины Цветаевой, но ее собственные истоки следует искать у других авторов: в балладной традиции, в мотиве оживающей статуи, в тематике „мертвых душ” (Эрнст Гофман, Василий Жуковский, Александр Пушкин, Николай Гоголь и пр.) и „живых трупов” (Одоевский, Федор Достоевский). Тема „мертвой невесты” более развернуто представлена в следующем рассказе настоящей группы.

Рассказ Осень (у Петровской есть и другой рассказ с тем же названием, входивший, наряду с рассказом Она, в ее дебютную публикацию в альманахе „Гриф” в 1903 году) следует рассматривать в качестве первой реплики в литературном диалоге с Ауслендером. Он был опубликован в № 12 журнала „Перевал”, и дядя Ауслендера, Михаил Кузмин, бывший в курсе начинающихся отношений писателей, оставил о рассказе следующую запись (18 ноября 1907 года): „Прислали Перевал, где Нина посвящает Сереже очень компрометантную вещь” (Kuzmin 426). Попробуем истолковать эту характеристику.

Отметим сразу, что Осень перекликается названием с рассказом второй группы - Весной. В обоих текстах содержится рефлексия героя над временем года: „Я давно уже не люблю осени. Может быть, с тех дней, когда иссякло безумно-юное опьяненье души, которое мы переживаем раз в жизни, только раз в жизни" (Petrovskaâ 100).

В обоих рассказах важен и мотив колокольного звона: „В этот час колокола поют нежными серебряными голосами” [Весной] (Petrovskaâ 38) - „Вы замечали, как осенью звонят колокола? Совсем особенно, точно сзывают мир на большой прощальный праздник" [Осень] (Petrovskaâ 101).

Описание женского портрета, висящего на стене комнаты в рассказе Becной, перекликается с описанием женщины, которую встречает герой Осени: „Нежное мертвое лицо с восковой белизной на висках, с синей тенью ресниц на холодных щеках выпуклым рисунком выступает из траурной рамы" (Petrovskaâ 105).

Мертвенность героини Осени оттеняется образом „мертвой невесты”, с которой у героя ассоциируется запах осенних цветов - тубероз: 
тонкий бледно-зеленый стебель, измученный и хрупкий, два-три [...] мертвенно белых цветка. В густом опьяняющем запахе сладкая отрава тленья и смерти. Может быть, так пахнет в комнате чьей-то мертвой невесты, и так же [...] влажно-холодны и тяжелы неподвижные пальцы сложенных рук (Petrovskâa 102).

С туберозами у Петровской были связаны отрицательные ассоциации, о чем можно судить по ее письмам к Брюсову. Например, от 10 августа 1905 года:

Барятинская прислала туберозы [...] я долго не могла понять, откуда у меня вдруг появилась такая непобедимая тоска. Как запахи цветов властвуют над душой... Они воскресили прошлую осень, нашу квартиру на осенних закатах, пахнуло чем-то страшным жутко-мертвенно-холодным (Brûsov, Petrovskaâ 110).

Возможно, импульсом к развитию этой образности послужило выражение „мертвенный цвет туберозы” из стихотворения Отцвели (1899) Константина Бальмонта, увлечение которым Петровская пережила еще до романа с Белым.

Тема „мертвой невесты”, на наш взгляд, продолжает тему „живого мертвеца", заданную в предыдущем рассказе сборника, однако здесь она не эксплицирована: читатель может лишь предполагать, что героиня - „призрак”, по окружающему ее ореолу смерти и тому безразличию, с которым она покидает героя. В петербургских письмах Петровской к Брюсову присутствует аналогичный образный ряд: отъезд, бледная мертвенность лица, белые цветы. 27 сентября 1907 года она пишет:

Он не может слышать о моем отъезде [...] Знаю, когда буду уезжать, он будет цепляться за меня холодными руками и лицо у него будет как у мертвых [...] Мне будет жалко расстаться с этим существом [...] У него весь облик такой, и лицо, и глаза, что нельзя смотреть без печали. Точно надломленный белый цветок (Brûsov, Petrovskâ̂ 240-241).

„Странным существом” называет герой Осени свою визави, подобно тому, как Петровская называет Ауслендера. Повторяется в рассказе и мотив проводов: герой бежит за поездом, чтобы сказать героине важные слова, но телега для багажа преграждает ему путь. Отличаются письмо и рассказ тем, что в письме атрибутами „мертвенности” наделяется Ауслендер, тогда как в рассказе в образе „мертвой невесты” представлена героиня. Здесь, как и в ряде других случаев, за „мужской” точкой зрения стоит „женский” опыт.

В отличие от рассказа Весной, в Осени эротическая линия сюжета не выражена - герои засыпают в объятьях друг друга: 
„До тебя меня не ласкал никто”, - говорит она серьезно, - „Тебя это радует или печалит?”. Ложимся близко. Нежные руки обвили мне шею душным кольцом. „Останься так”, - шепчет она, засыпая, - „Засни около меня. Мы близки давно, точно с детства я знала тебя". Я засыпаю и просыпаюсь. У меня на плече ее волосы и близко ровное дыханье (Petrovskaâ 108).

Все же Кузмину и это показалось достаточным, чтобы назвать рассказ „компрометантным”. Кроме того, Петровская останавливалась в том же доме, где жил Ауслендер, о чем, как и о его признаниях в любви, Брюсов был уведомлен. В рассказе, однако, в любви признается героиня. Она же оказывается инициатором расставания, так как уезжает на следующее утро после описанной ночи. В данном случае трудно судить, спроецирован ли образ героини рассказа на Ауслендера, или все-таки является автопроекцией.

Возможно, „невинность” Ауслендера (в письмах Петровская многократно называет его ребенком), его непохожесть на прочих „прохожих” послужила препятствием для более пылкого романа. Теми же чертами Петровская наделила и героиню Осени. В то же время искренним, хоть и неумелым стремлением к любви она наделила героя, тем самым усложняя интерпретацию для непосвященного читателя.

Подобный прием используется и в других рассказах, где Петровская наделяет мужского героя собственными (из писем) психологическими и эмоциональными чертами, однако с точки зрения фабулы делает его похожим скорее на Брюсова (Раб, Северная сказка). На фоне этого закономерным выглядит и ауслендеровский прием „переодевания” Анжелики в Пьетро (Kopaбельщики). Возможно, это своеобразное „разоблачение” сюжетной техники Петровской, с которой он мог ознакомиться по предварительным публикациям ее рассказов.

Герой Осени описан как утрачивающий способность слышать голос Любви. Теперь он слышит другие звуки: „пронзительно-грустный” звон колоколов и то, как „туберозы за черными стеклами витрин немым цветочным языком рассказывают странную волнующую сказку о мертвой невесте" (Petrovskâ̂ 105).

Любовь словно заранее подсказывает герою, что его невеста „мертва”, и сам он тоже это чувствует, сравнивая женщину с персонажами рассказов Мориса Метерлинка „о странной бесстрастной любви, за плечами которой всегда дышит прекрасная нежная смерть" (Petrovskaâ 104).

Умерла Любовь и для героя - с тех пор, как „иссякло безумное опьянение души, которое мы переживаем раз в жизни" (Petrovskaâ 100). Характеристика рассказов Метерлинка, в которых за любовью следует смерть, на наш взгляд, иллюстрирует и собственные взгляды Петровской. Эта же идея содержится и в словах героини рассказа Бродяга (отказ убивать любовь бы- 
том), в описании „умерших” призраков, и на макросюжетном уровне сборника: ожидание - встреча - предательство - смерть.

Адресуя рассказ Ауслендеру, Петровская могла интерпретировать его как извинение или оправдание холодности в ответ на его признания (если верить ее письмам): осень - пора смерти, а не любви. В составе сборника оно приобретает несколько иной смысл, о чем мы скажем ниже. Понятные Ауслендеру смыслы оставались туманными для постороннего читателя, хотя бы потому, что рассказ написан от мужского лица. Но это не помешало Кузмину счесть Осень „компрометантной вещью”.

Последний рассказ книги, Любовь, тоже был впервые опубликован после петербургских встреч Петровской с Ауслендером. Жанровый подзаголовок - „страницы из записной книжки” - ретроспективно подсвечивает и все предыдущие рассказы, изложенные от первого лица.

Герой сидит на „твердой белой земле” „в чистой тишине лесного ноябрьского утра" и пишет исповедь о совершенном ночью убийстве. Накануне он был с возлюбленной в ресторане и, „предчувствуя близкий и страшный конец”, спросил, „любит ли она его” (Petrovskaâ 114). Ответ героини оправдал его предчувствия:

Твоя любовь всегда была требовательная, грубая. Я чувствую, как она определяет каждый мой шаг и говорит: ты должна. Давай же, наконец, дадим друг другу свободу и не будем требовать ничего (Petrovskaâ 115).

Во время разговора герой замечает в женщине черты, отсылающие к теме вампиризма или призраков:

[...] зубы у нее белые, острые, как у тигра. Может быть, ей хочется прокусить мне шею там, где кончается белый край воротничка. Прокусить и смеяться красными, испачканными кровью губами (Petrovskaâ 118).

Такое же желание возникает и у героя Призраков, когда он целует женщину: „Ах! жестоко и грубо вонзиться в них зубами, чтобы выступили мелкие капельки крови, чтобы раздался живой испуганный крик” (Petrovskaâ 98).

Из ресторана действие переносится в комнату героя, где женщина сообщает, что уедет на неделю. Однако герой достает из ящика стола револьвер и убивает женщину. Нечто подобное чуть не случилось и с самой Петровской: 14 апреля 1907 года во время публичной лекции Белого она совершила покушение на жизнь Брюсова.

Совершив убийство, герой направляется к городским окраинам, где, под шум сосен, хочет петь „новую песнь без слов - о Любви и Смерти, о Вечном Покое и освобождении от мук", а затем замерзает в ожидании любви, представляя, как 
вдали, в колючей чаще елок, встанет старый лесной Бог, протянет дряхлую, нежную руку и скажет: Благословенны и смерть и любовь (Petrovskâ̂ 123).

Текст содержит сюжетную параллель к первому рассказу сборника Она nридет: обе героини упрекают героя в слишком требовательной любви, подразумевающей отказ от всех прочих сфер жизни. Однако реагирует рассказчик по-разному: в рассказе Она придет он интерпретирует слова женщины как ее несоответствие своему идеалу, а в рассказе Любовь - не может смириться с тем, что героиня больше не любит его. Жестокость женского персонажа („красивая, жестокая, с равнодушно-веселыми глазами” (Petrovskaâ $115)$ и внешность femme fatale сближают ее с женщиной из рассказа первой группы - Я и собака. Но поведение мужского персонажа отличается: вместо покорного „идеального ожидания” он решает убить свою возлюбленную и себя, поскольку в прошлом, когда их чувства были ярче, он решил, что „не будет разлуки ни в жизни, ни в смерти" (Petrovskaâ 117).

Фразой, объясняющей связь любви и смерти (не исключено фонетическое обыгрывание слов Amor и mortem), заканчивается рассказ и сборник о Святой Любви. Сближение любви и смерти объясняется, на наш взгляд, их общей для автора противопоставленностью жизни. Говоря словами героини рассказа Бродяга, и то и другое делает самых ничтожных „богами”.

Выводы. Центральной темой сборника Петровской является заявленная в заглавии Святая Любовь. Все рассказы (кроме Призраков) представляют собой вариации сюжета об ожидании или встрече героя с Любовью. Вместе они образуют единый сюжет, который развертывается повторно, словно по спирали, но только на третьем витке осуществляется полностью.

Полный цикл включает в себя темы: ожидание Любви - встречу с Любовью - отказ от Любви - и смерть без Любви. В первых четырех рассказах эта схема реализуется не полностью, потому что Весной (№ 4) представляет собой скорее шаг назад, соответствуя второй стадии. Далее следуют еще три рассказа, которые реализуют только первые три этапа, причем в седьмом рассказе вина героя уже искупается. Вполне можно было бы представить семичастный сборник, где рассказом Северная сказка (№ 7) все бы и заканчивалось. Скорее всего, в таком составе сборник был бы посвящен Брюсову и имел бы более радужный характер.

Однако в жизни Петровской появился Сергей Ауслендер, и был написан рассказ Осень, который, как кажется, задал новую тенденцию описания жизни post mortem - без ярких страстей и подлинных чувств. Видимо, следом появилась Любовь как история о том, чем кончается подобная бесчувственность, а Призраки писались уже прямо для сборника, Петровская просто не успела их отдельно опубликовать. Получившаяся триада уравновесила об- 
щую композицию как заключительный „виток”, в котором оказались собранными три „эпилога” трех „попыток” встретиться с Любовью.

При этом и в трех заключительных рассказах прослеживается некоторое развитие, подобное тому, что мы видим в первых двух „витках” композиционной спирали: самая безжизненная часть все-таки Призраки (№ 8), в Осени (№ 9) любовное свидание все же происходит, хотя „музыка” и не звучит. Любовь (№ 10) же не только сюжетно реализует тему убийства, но одновременно и разрушает „мертвенный” порядок жизни, как бы сгущая мрак до такой степени, после которой может быть только рассвет и возрождение (ср. „брюсовский” мотив предрассветной „третьей стражи”).

Как мы уже заметили, письма и проза Петровской составляют довольно тесное единство: письма объясняют прозу, но и проза, по-своему, объясняет письма и жизнь. Уже в 1903-1904 годах, когда Петровская едва успела опубликовать в альманахе супруга первые рассказы, ее имя значилось в качестве объекта посвящения над стихами Николая Пояркова, Александра Рославлева и Бальмонта, в связи с чем Николай Богомолов заключает, что

адепты „нового искусства” воспринимали явление Петровской как проявление чаемого единства литературы и жизни, того самого жизнетворчества, которое, по признанию многих и многих, становилось одним из коренных пунктов символизма (Bogomolov 47).

Теперь, будучи не только вдохновительницей поэтов, но и автором сборника, она обладала достаточным символическим и литературным капиталом, чтобы самостоятельно включить в жизнетворческую „игру” более молодого писателя. Эконен вслед за другими исследователями справедливо указывает, что „название сборника заимствовано из стихотворения Андрея Белого Предание, впервые опубликованного как Sanctus Amor в 1903 г.” (Èkonen 267).

Но что означает это заимствование? Свое стихотворение Белый посвятил мужу Петровской, Кречетову (Соколову), и в нем повествуется о любви пророка и сивиллы, их расставании и вечном ожидании, на которое обрекает себя сивилла. Это ли Любовь, воспетая Петровской? По мнению Сергея Гречишкина и Александра Лаврова,

стремление Андрея Белого воспеть любовь как средоточие томлений по запредельному, как просветленный выход в недоступные обыденному миропознанию сферы, с наибольшей полнотой раскрылось в этом стихотворении (Lavrov, Grečiškin 85).

Во время романа с Петровской Белый проповедовал ей идеи „небесной любви", в которые она искренне верила, но не могла ограничиться лишь ими: для Петровской любовь не была делима на „небесную” и „земную”, но являлась целостной и святой во всех ее проявлениях. Ср. пассаж из статьи 
Лаврова Мифотворчество „Аргонавтов”, содержащий цитату из письма Петровской к Белому:

\begin{abstract}
Петровская оказалась строптивой ученицей на „пути посвящения”: она хотела видеть в своей любви не только символ высших начал, но и нечто самоценное, и противилась „мистериальному” ригоризму Белого, защищая свое право на цельное земное чувство. „Во мне звучат «фальшивые ноты с точки зрения религиозной любви»? - писала Петровская в ответ на укоризненное письмо Белого [...] Я знаю ее одну святую и безгрешную всегда, даже в ее яркой земной красоте [...] Ты же разрываешь, нарушаешь, делишь вместо того, чтобы принять ее святую полноту" (Lavrov 1978: 167).
\end{abstract}

Роман Белого и Петровской завершился весьма скоро, однако писательница сохранила верность своим представлениям о святости любви и опиралась на них в последующих романах, в том числе с Брюсовым. Отсылка к стихотворению Белого может рассматриваться в полемическом ключе. Следует упомянуть и посвященное Петровской стихотворение Ходасевича Sanctus Amor, опубликованное в его дебютном сборнике Молодость (1908), но написанное ранее (1906-1907). Ходасевич читал отдельные рассказы Петровской и знал о готовящемся выходе ее сборника и потому мог назвать свое стихотворение именно так. В тексте отражена та же мысль, что господствует в финальных рассказах сборника Петровской, - об омертвении души в отсутствии любви. Возможно, это и объясняет желание Петровской выпустить свою книгу одновременно со сборником Ходасевича, о чем говорилось выше.

Мы полагаем, что в Ауслендере Петровская видела адресата, способного понять ее философию Святой Любви. Если в отношениях с Белым и Брюсовым она выступала в роли ученицы и „просительницы”, но так и не смогла воплотить счастливую версию своего жизнетворческого проекта, то в случае с Ауслендером ей представлялась возможность реализовать свой замысел по собственному сценарию.

Сборник Sanctus Amor был своего рода учебником Любви. Распределение мужских и женских ролей при этом было несущественным, поскольку сама идея Святой Любви была универсальной. Отчасти этим можно объяснить выбор мужского героя-повествователя для всех рассказов: знакомясь с книгой, читатель-мужчина должен был быть восприимчивее к мыслям и чувствам героя-мужчины. Конечно, нельзя сбрасывать со счетов и желание завуалировать автобиографический слой рассказов для широкой публики.

Вместе с тем, самим актом посвящения Петровская создавала, а вернее, воспроизводила в литературной сфере новый любовный треугольник. Прежде ей приходилось выбирать между Соколовым и Белым, между Белым и Брюсовым (так же, как Брюсову - между ею и супругой). Теперь напря- 
жение возникло между Брюсовым и Ауслендером. Брюсов, разумеется, считывал биографические коды и лучше Ауслендера понимал магистральные образы и идеи рассказов. Номинально адресовав сообщение Ауслендеру, Петровская, в действительности, обращала это сообщение сразу (как минимум) к двум адресатам, каждый из которых воспринимал его по-своему.

Для Ауслендера это был своего рода ключ к пониманию мировоззрения Петровской, предложение определенной роли и, вероятно, обещание возможного романа. Для Брюсова это было предупреждением о том, что Петровская может выбрать другого. В отношении Ауслендера сборник выполнил свою функцию и вскоре после публикации он отправился с писательницей в путешествие в Италию ${ }^{2}$, возможно, в надежде познать Святую Любовь. Отчасти этот план удался, и поездка получила отражение в некоторых последующих произведениях Ауслендера, из которых наиболее значимое - роман с ключом Последний спутник (1913).

\section{Библиография}

Belyj, Andrej. „Nina Petrovskaâ. Sanctus Amor. 1908 g. Knigoizdatel'stvo «Grif»”. Vesy, 3, 1908, s. $90-92$.

Blok, Aleksandr. Polnoe sobranie sočinenij i pisem v 20 t. T. 8. Moskva, Nauka, 2010.

Bogomolov, Nikolaj. „Zametki k tekstu perepiski”. Brûsov Valerij, Nina Petrovskaâ. Perepiska: 1904-1913. Red. Nikolaj Bogomolov, Aleksandr Lavrov. Moskva, Novoe literaturnoe obozrenie, 2004.

Brûsov Valerij, Nina Petrovskaâ. Perepiska: 1904-1913. Red. Nikolaj Bogomolov, Aleksandr Lavrov. Moskva, Novoe literaturnoe obozrenie, 2004.

Èkonen, Kirsti. Tvorec, Sub"ekt, Žensîna. Strategii ženskogo pis'ma v russkom simvolizme. Moskva, Novoe literaturnoe obozrenie, 2011.

Gamsun, Knut. Sobranie sočinenij v 12 t. Pri bližajšem učastii K. Bal'monta, Û. Baltrušajtisa i S. Polâkova. T. 5. Sankt-Peterburg, Šipovnik, 1908-1910.

Garetto, Èl'da. „Žizn' i smert' Niny Petrovskoj”. Minuvšee. Istoričeskij al'manah. Nr 8. Red. Vladimir Alloj. Paris, Atheneum, 1989, s. 7-138.

Gippius, Zinaida. Sobranie sočinenij v 15 t. My i oni. Literaturnyj dnevnik. Publicistika 1899-1916 gg. T. 7. Moskva, Russkaâ kniga, 2003.

Gračeva, Alla. „Vâčeslav Ivanov - geroj prozy Sergeâ Auslendera”. Memento Vivere. Sbornik pamâti L. N. Ivanovoj. Red. Kseniâ Kumpan, Elena Obatnina. Sankt-Peterburg, Nauka, 2009, s. 307-317.

Hodasevič, Vladislav. Nekropol'. Vospominaniâ. Moskva, Sovetskij pisatel', 1991.

${ }^{2}$ Важную роль в интерпретации событий сыграла и публикация Огненного ангела Брюсова, который молодые писатели читали во время путешествия. Вполне вероятно, что именно в это время у Ауслендера складывался замысел будущего произведения, ставшего своего рода ответом и на брюсовский роман. 
Hvan, Aleksandra. Metafizika lûbvi v proizvedeniâh A. I. Kuprina i I. A. Bunina. Dissertaciâ na soiskanie učenoj stepeni kandidata filologičeskih nauk. Moskva, In-t hudož. tvorčestva, 2002.

Kuzmin, Mihail. Dnevnik 1905-1907. Red. Nikolaj Bogomolov, Sergej Šumihin. Sankt-Peterburg, Izd-vo Ivana Limbaha, 2000.

Lavrov, Aleksandr. „Mifotvorčestvo «Argonavtov»”. Mif - fol'klor - literatura. Leningrad, Nauka (Leningradskoe otdelenie), 1978, s. 137-170.

Lavrov, Aleksandr. „Valerij Brûsov i Nina Petrovskaâ: biografičeskaâ kanva k perepiske”. Valerij Brûsov, Nina Petrovskaâ. Perepiska: 1904-1913. Red. Nikolaj Bogomolov, Aleksandr Lavrov. Moskva, Novoe literaturnoe obozrenie, 2004.

Lavrov, Aleksandr, Sergej Grečiškin. „Biografičeskie istočniki romana Ognennyj angel (I)”. Wiener slawistischer Almanach. Bd. 1, 1978. Web. 13.01.2020. http://periodika.digitale-sammlungen. de/wsa/Blatt_bsb00000467,00079.html.

Lotman, Ûrij. Istoriâ i tipologiâ russkoj kul'tury. Sankt-Peterburg, Iskusstvo - SPB, 2002.

Mihajlova, Mariâ. „,Sanctus Amor. Kommentarii”. Nina Petrovskaâ. Razbitoe zerkalo. Proza. Memuary. Kritika. Moskva, B.S.G.-Press, 2014.

Minskij, Nikolaj. Pri svete sovesti: Mysli i mečty o celi žizni, 2-e izd. Sankt-Peterburg, tip. Û. N. Èrlih, 1897.

„Novosti literatury”. Volga. Političeskaâ i obŝestvenno-literaturnaâ gazeta, 4 (fevral'), 1908.

Petrovskaâ, Nina. Sanctus Amor. Moskva, Grif, 1908.

Pil'skij, Petr. „Buduarnaâ literatura: Mimočka v literature: Sanctus Amor rasskazy Niny Petrovskoj”. Svobodnye mysli, 34, 1907.

Samarin, Aleksej. „Nina Petrovskaâ v romane Sergeâ Auslendera Poslednij sputnik (1913)”. Russkâ̂ filologiâ. Sbornik naučnyh rabot molodyh filologov. Red. Timur Guzairov. Tartu, Tartu Ülikooli Kirjastus, 2018, s. 161-175.

Ŝerbakov, Rem, Elizaveta Murav'eva. „Iz perepiski N. I. Petrovskoj”. Minuvšee. Istoričeskij al'manah. Red. Vladimir Alloj. Nr 14. Moskva-Sankt-Peterburg, Atheneum-Feniks, 1993, s. 367396.

Tyryškina, Elena. „Žizn' v prostranstve dekadansa (Nina Petrovskaâ)”. Studia Slavica Academiae Scientiarum Hungaricae, 47/1-2, 2002, s. 133-145. 
